Journal of Social Sciences (COES\&RJ-JSS)

ISSN (E): 2305-9249 ISSN (P): 2305-9494

Publisher: Centre of Excellence for Scientific \& Research Journalism, COES\&RJ LLC

Online Publication Date: $1^{\text {st }}$ July 2018

Online Issue: Volume 7, Number 3, July 2018

https://doi.org/10.25255/jss.2018.7.3.215.243

\title{
Status and proliferation of private schools in Marawi city: Implications on the quality of education
}

\author{
Dr. Sonayah D. Guimba \\ https://orcid.org/0000-0001-5677-4425 \\ Faculty, Department of Management \\ College of Business Administration \& Accountancy \\ MSU Marawi City, Philippines
}

\begin{abstract}
:
This descriptive research design was conducted to determine the status of the increased number of private schools and its proliferation in Marawi City based on the 1998 Revised Manual for Private Education particularly in the compliance of government requirements and its implications to the quality of education. A total of twenty-six private schools served as the respondents of this study. Many developing nations lack adequate resources to fund public schools and universities. Faced with growing lower-and middleclass populations that are too often underserved, these nations increasingly rely upon private education to complement public education. The increase in the number of private schools could be alarming especially when it comes to quality education. Ideally, private schools should always be adjunct to quality education, yet it is sad to note that the prevailing perceptions on the proliferation of private schools are not accompanied by quality. Findings revealed that the relationship between the profile of the school and the extent of compliance with government requirements revealed no correlation at all, while the t-test revealed a not significant relationship between the teachers' profile and the level of passing standardized and board examinations. For the relationship between the profile of the owners'/administrators and the extent of participation in extension and community outreach programs, except for the monthly income was found to have not significant relationship with extension and community outreach programs. Lastly, the test of difference between the owners'/administrators' and teachers' perceptions on the factors for the proliferation of private schools revealed a not significant difference.
\end{abstract}

Keywords :

private schools, Marawi City, Philippines, proliferation of private schools

\section{Citation:}

Guimba, Dr. Sonayah D. (2018). Status and proliferation of private schools in Marawi city: Implications on the quality of education; Journal of Social Sciences (COES\&RJ-JSS), Vol. 7, No.3, pp.215-243; https://doi.org/10.25255/jss.2018.7.3.215.243.

This work is licensed under a Creative Commons Attribution 4.0 International License. 


\section{Introduction}

Philippine education institutions varied in quality. Some universities were excellent; others were considered "diploma mills" with low standards, especially those in poor rural areas. The area in the Autonomous Region in Muslim Mindanao (ARMM) has been historically disadvantaged relative to the rest of the Philippines, obtaining fewer social and economic benefits and suffering disruptions from armed conflict. As a result, its social and economic indicators are the lowest in the country. About 21 percent of the barangays in the ARMM are without schools. The high drop-out rates and the correspondingly high illiteracy rate- along with conflict and the lack of job-creating investment in the region have contributed to high unemployment.(www.equalls.org/03.07.09/8:38)

Education is very essential to the Filipinos and it is a mandate in the Philippine Constitution. Quality education is an essential element for economic growth, upward social mobility, and competition in the interconnected world economy.

There is growing evidence that private participation in education can improve effectiveness in developing countries in cost-effective manner and without compromising equity. Moreover, a number of studies demonstrate that private participation can encourage the public sector to improve their quality and efficiency. This is brought by the competition among providers of services which causes the lowering of costs and improves responsiveness to the needs of consumers (Journal on Knowledge, Creativity and Transformation of Societies,2007).

The increase in the number of private schools could be alarming especially when it comes to quality education. Ideally, private schools should always be adjunct to quality education, yet it is sad to note that the prevailing perceptions on the proliferation of private schools are not accompanied by quality.

Thus, this study was conducted to determine the status of the increased number of private schools and its proliferation in Marawi City based on the 1998 Revised Manual for Private Education particularly in the compliance of government requirements and its implications to the quality of education.

\section{Literature Review}

\section{Theoretical Framework}

This study is best to examine from multiple perspective anchored from its underpinning theories which give basis to the interrelated factors for the proliferation of private schools in particular in Marawi City.

This study takes into consideration the Functionalist Theory and the Conflict Theory. Functionalism is a social paradigm that views society as a system of interdependent parts, or subsystems. For the functionalist, education is an institution that functions to fulfill the needs of the society and that education exists to impart knowledge to the students that they will need to function in everyday life.

The functionalists' three broad functions are socialization, skills provision, and role allocation. Durkheim and Talcott Parsons (2009), another functionalist theorist saw 
education as an essential agency of socialization whose function is to transmit common values to the next generation.

In the idea of conflict theory, it is rooted from Karl Marx, the great German and political activist.The people that hold powers are the ones who have control of what are perceived as scarce resources, like money, land, political influenced and education(www.grinnell.edu/courses/soc/IntroTheories/Conflict.html/03.08.09/9:33).Thi $s$ theory implies that educational institutions serve the interest of those who dominate the economy, namely the upper class, and not all social groups may have the same level of access to education.

Expounding on this theory, those parents who can afford to pay the cost of private schools would likely benefit from the quality of education offered by the private schools while those with much lower income could not do otherwise.

Elaborating further on the conflict theory and the commodification of education, education is a special product in a sense that it is meant to increase the production of wealth for the future.

Another theory is the political-economy theory in the determination of education funding and quality (De la Croix and Doepke, 2007). This theory suggests that the structure of the political system has effects with the quality of education offered by public schools thereby benefiting the private schools in return.The quality of public schooling, in turn, is determined through a political-economy mechanism whereby the government is responsive with the needs of the public school sectors.

There are many indicators of quality education. For this study, it explored four important elements that could lead to its attainment. These four elements are: (1) physical; (2) human elements; (3) quality content; and (4) quality outcomes.

\section{Related Studies}

A number of researchers were found to be value and relevant to the present investigation. One was the case study conducted by Tooley and Gulosino (2000) found that private schools in many depressed suburban and rural areas are charging minimal fees yet offering quality education. Even low-income families are responding to the perceived inadequate and poorly managed public schools by sending their children to private schools instead. Private schools are able to maximize available resources in their immediate environment whether they operate at low end profits or purely as a nonprofit association.

Additionally, in the study of Jimenez (1991) on the relative efficiency of private schools in some developing countries such as the Philippines, Colombia, Dominican Republic, Tanzania and Thailand resulted that private schools generally outperform public school students on standardized math and language tests. This finding holds even after accounting for the fact that, on average, private school students in these countries come from more advantaged backgrounds than their public school counterparts. 
The question on whether private schools provide a better education than public schools depends largely upon the student background.Thus, the ratio of relative effectiveness to relative cost is consistently greater than one. These results indicate that private schools are more efficient than public schools, at least for secondary schools in the sample countries. The findings of the study have more implications on policy. Over restrictive regulations on private schools (including outright prohibition in some countries) may be suppressing an efficient way to provide education.

\section{Methodology}

This study employed a descriptive research design in the analysis and interpretation of data on the profile of the respondents and the status of the private schools in Marawi City. An initial survey was conducted for the listing of the private schools and their physical profile.

A total of twenty-six private schools served as the respondents of this study. The data gathered were analyzed using the statistical tools such as frequency, percentage and weighted mean (WM). For the establishment of relationship among variables used and the testing of perception difference among the respondents, Pearson Product Moment Co-efficient of Correlation and t-test were used. Additionally, this study was conducted in Marawi City which is the center and premier urban center of the province of Lanao del Sur. Furthermore, the respondents of this study are the school owners, administrators and teachers of the various private schools in Marawi City as of Academic Year 20082009. The following table shows the List of Private Schools in Marawi City with their Corresponding Population and Sample Size.

Table 1

List of Private Schools in Marawi City with their Corresponding Population and Sample

Size

\begin{tabular}{|l|l|l|l|l|}
\hline \multirow{2}{*}{ Name of Private School } & \multicolumn{2}{l|}{ Owners/Administrators } & \multicolumn{2}{l|}{ Teachers } \\
\cline { 2 - 5 } & $\begin{array}{l}\text { Populatio } \\
\text { n Size }\end{array}$ & Sample Size & $\begin{array}{l}\text { Populatio } \\
\text { n Size }\end{array}$ & $\begin{array}{l}\text { Sample } \\
\text { Size }\end{array}$ \\
\hline Philippine Integrated School & 4 & 3 & 50 & 17 \\
\hline Ibn Siena Integrated School & 4 & 3 & 120 & 42 \\
\hline Al Khwarizmi International College & 2 & 2 & 5 & 2 \\
\hline $\begin{array}{l}\text { MasiricampoAbantas Memorial } \\
\text { Science Academy }\end{array}$ & 6 & 5 & 18 & 6 \\
\hline $\begin{array}{l}\text { Ranao Child Development Center } \\
\text { MubongMarzok Memorial College }\end{array}$ & 2 & 2 & 16 & 6 \\
\hline $\begin{array}{l}\text { Buaramedical College } \\
\text { Cali }\end{array}$ & 2 & 2 & 8 & 3 \\
\hline Foundation & 2 & 2 & 20 & 7 \\
\hline
\end{tabular}


Status and proliferation of private schools in Marawi city ...

\begin{tabular}{|c|c|c|c|c|}
\hline Dansalan Polytechnic College & 3 & 2 & 10 & 3 \\
\hline $\begin{array}{l}\text { Datu Mala - Muslim Mindanao } \\
\text { Islamic College }\end{array}$ & 3 & 2 & 29 & 10 \\
\hline $\begin{array}{ll}\text { JamiatuMarawi } & \text { Al-Islamia } \\
\text { Foundation } & \end{array}$ & 4 & 3 & 36 & 12 \\
\hline Jamiatu Muslim Mindanao & 4 & 3 & 25 & 9 \\
\hline Jamiatul Philippine Al-Islamia & 4 & 3 & 102 & 35 \\
\hline Lake Lanao College & 2 & 2 & 49 & 17 \\
\hline $\begin{array}{l}\text { Lanao Islamic Paramedical College } \\
\text { Foundation }\end{array}$ & 3 & 2 & 17 & 6 \\
\hline Mapandi Memorial College & 5 & 4 & 54 & 19 \\
\hline $\begin{array}{l}\text { Marawi Capitol College Foundation } \\
\text { Inc. }\end{array}$ & 4 & 3 & 27 & 9 \\
\hline $\begin{array}{lll}\text { Mindanao } & \text { Islamic } & \text { Computer } \\
\text { College } & & \end{array}$ & 3 & 2 & 20 & 7 \\
\hline Pacasum College & 3 & 2 & 15 & 5 \\
\hline Philippine Muslim Teachers College & 3 & 2 & 8 & 3 \\
\hline $\begin{array}{l}\text { Senator Ninoy Aquino College } \\
\text { Foundation }\end{array}$ & 11 & 9 & 37 & 13 \\
\hline $\begin{array}{l}\text { Philippine Engineering Agro } \\
\text { Industrial College Inc. }\end{array}$ & 3 & 2 & 15 & 5 \\
\hline Marawi Foundation Academy & 3 & 2 & 16 & 6 \\
\hline $\begin{array}{l}\text { Aba Al Khair Integrated of Lanao } \\
\text { Institute }\end{array}$ & 2 & 2 & 29 & 10 \\
\hline Shapiya Integrated School & 2 & 2 & 13 & 5 \\
\hline HOPE Healthcare Training Institute & 1 & 1 & 9 & 3 \\
\hline Children's Learning Center & 2 & 2 & 8 & 3 \\
\hline Total & 87 & 71 & 756 & 262 \\
\hline
\end{tabular}

This study made use of a researcher-made questionnaire patterned from other researches with similar purpose and validated in other groups prior to its actual distribution to the actual respondents. The questionnaireconsists of three parts. Part I sought to gather information on the factors/reasons for the proliferation of private schools in Marawi City based on religious, cultural, social, economic and political factors. Part II focused on the status of the private schools which includes their profile as well as those of the owners/administrators and teachers. Part III explored the extent of performance of the private schools based on their compliance with government requirements, passing of standardized and board examinations.

\section{Results and Discussion}


The main goal of this study is to determine the status of the increased number of private schools and its proliferation in Marawi City based on the 1998 Revised Manual for Private Education particularly in the compliance of government requirements and its implications to the quality of education.

The data were presented in five parts. The first part focused in the status of the private schools which includes the profile of the schools, the owners/administrators and the teachers. The second part deal with factors for the proliferation of private schools in Marawi City for the school year 2008-2009. The third part deals with the school performance. The fourth determined the relationship between the status of the private schools and their extent of performance and the fifth part discussed the difference between the owners/administrators and teachers perceptions on the factors/reasons for the proliferation of private schools. The following are the major findings of the data analysis.

Table 2

Frequency and Percentage Distribution of the Private School's type of Operation

\begin{tabular}{|l|l|l|}
\hline Types of Operation & Frequency & Percentage \\
\hline $\begin{array}{l}\text { With permit from } \\
\text { CHED/DepEd/TESDA }\end{array}$ & 44 & 62.00 \\
\hline Recognized by foreign agency & 2 & 2.80 \\
\hline $\begin{array}{l}\text { Others (with permit/registration from } \\
\text { either CHED/DepEd/TESDA/SEC }\end{array}$ & 25 & 35.20 \\
\hline Total & 71 & $100 \%$ \\
\hline
\end{tabular}

The finding then is considered a positive effort of the school operators. This means that they are law-abiding by securing the necessary permit for them to operate and granting them the legal personality. In addition, the registration obtained by the school from the SEC provides security to the juridical personality of the school for the protection of its properties. This means also that the school wants to strengthen its corporate capability by maintaining a regulatory system set by the Commission.

Table 3

Frequency and Percentage Distribution of the Private Schools' Type of Organization

\begin{tabular}{|l|l|l|}
\hline Type of Organization & Frequency & Percentage \\
\hline Single Proprietorship & 20 & 28.20 \\
\hline Partnership & 12 & 16.90 \\
\hline Foundation & 30 & 42.30 \\
\hline Non-Stock Non-Profit & 2 & 2.80 \\
\hline Profit-Oriented, Stock Corporation & 7 & 9.90 \\
\hline Total & 71 & $100 \%$ \\
\hline
\end{tabular}

The finding stresses how school operators prefer to be organized as a foundation because of its versatile structure that could be registered as a company but without shareholders and bound by the founder's intentions not contrary to law. This is linked with the characteristics of a foundation and inclined to charitable activities that benefit 
the schools in outsourcing financial support. Another advantage of a private foundation is the special consideration afforded it by the government through tax exemptions.

Table 4

Frequency and percentage Distribution of the Private Schools' Type of Curricula Adopted

\begin{tabular}{|l|l|l|}
\hline Type of Curricula Adopted & Frequency & Percentage \\
\hline Integrated & 31 & 43.70 \\
\hline Secular & 27 & 38.00 \\
\hline Non-Secular & 13 & 18.30 \\
\hline & & \\
\hline TOTAL & 71 & $100 \%$ \\
\hline
\end{tabular}

This finding supports the growing preference of parents in integrated schools over secular and non-secular schools. This is an influence of the success of some integrated schools founded in Marawi City especially preschool, elementary and high school levels. One of the popular integrated schools favored by most parents for its quality is the Ibn Siena Integrated School (ISIS). The ISIS phenomenon may be considered the first venture to implement a curriculum on integrated education. The integrated curriculum as implemented in the ISIS is inspired by the global trend on the Islamization of knowledge.

Table 5

Frequency and Percentage Distribution of the Private Schools According to their Program of Offerings

\begin{tabular}{|l|l|l|}
\hline Program Offerings & Frequency & Percentage \\
\hline $\begin{array}{l}\text { Pre-school, Elementary and } \\
\text { Secondary }\end{array}$ & 23 & 32.40 \\
\hline Preschool and Tertiary & 2 & 2.80 \\
\hline Vocational & 2 & 2.80 \\
\hline Tertiary & 8 & 11.30 \\
\hline All of the above & 36 & 50.70 \\
\hline Total & 71 & $100 \%$ \\
\hline
\end{tabular}

The data show that the common program levels being offered are that of preschool and secondary. Preschools are very much in demand and it is where quality education should start. It is generally observed that parents are presently aware of the importance of early start in education through preschool. The crowding in the secondary levels may be attributed to the subsidy from government and this assistance plays a major role in the operation of the schools in support to the tuition fees collected.

Table 6

Frequency and Percentage Distribution of the Private Schools' Physical Structure

\begin{tabular}{|l|l|l|}
\hline Physical Structure & Frequency & Percentage \\
\hline Type of Building & & \\
Fully Concrete & 58 & 81.70 \\
Semi Concrete & 13 & 18.30 \\
\hline
\end{tabular}




\begin{tabular}{|l|l|l|}
\hline Total & 71 & $100 \%$ \\
\hline Mode of Acquiring the Building & & \\
Owned & 35 & 49.30 \\
Rented & 17 & 23.90 \\
Purchased & 19 & 26.80 \\
Total & 71 & $100 \%$ \\
\hline
\end{tabular}

It has been generally observed that most buildings in Marawi City are fully concreted in both public and privately-owned buildings. The superior protection offered by these concrete buildings against cold climate, storms and criminal intentions make it ideal for learning. In addition, the concrete buildings have high level resistance to fire and noise. In Marawi City, most of the private school buildings are personally owned. It is easier for a school to be established and be registered if the buildings are owned by the school operators themselves. Bigger classroom capacity is much preferred and designed for multipurpose activities. Inasmuch as most of the private schools do not have enough space for auditoriums or function halls, classrooms are designed as a convertible to function halls for general meetings, symposiums, seminars and parties.

Table 7

Frequency and Percentage Distribution of the Private Schools' Source of Funds

\begin{tabular}{|l|l|l|}
\hline Source of Funds & Frequency & Percentage \\
\hline Enrolment and Tuition Fees for the & 28 & 34 \\
\hline $\begin{array}{l}\text { Enrolment, Tuition and subsidy for } \\
\text { Government }\end{array}$ & 47.90 \\
\hline $\begin{array}{l}\text { Fund Assistance/Contribution from Local } \\
\text { Sponsors, NGO's and PO's }\end{array}$ & 5 & 7.04 \\
\hline $\begin{array}{l}\text { Enrolment, Tuition and Income Generating } \\
\text { Projects }\end{array}$ & 4 & 5.63 \\
\hline Total & 71 & $100 \%$ \\
\hline
\end{tabular}

Enrolment and tuition fees alone are not sufficient for the entire operation of the schools, thus there is a need for financial assistance form the government and NGO's such as the Fund Assistance to Private Education (FAPE) to standardize the school programs and related support services and the Government Assistance to Students and Teachers in Private Education(GASTPE) Program that aids needy secondary students left out by the public school system's limited facilities and driven to enroll in private institutions.

Table 8

Mean Ratings of the Private Schools' Achievement of their Mission, Vision, Goals and Objectives

\begin{tabular}{|l|l|l|l|l|}
\hline \multirow{2}{*}{ Key Factors/Areas } & \multicolumn{3}{|l|}{ Owners/Administrators } & \multicolumn{2}{l|}{ Teachers } \\
\cline { 2 - 5 } & $\begin{array}{l}\text { Weighted } \\
\text { Mean }\end{array}$ & Description & $\begin{array}{l}\text { Weighted } \\
\text { Mean }\end{array}$ & Description \\
\hline $\begin{array}{l}\text { Religious mission, vision, } \\
\text { goals and objectives }\end{array}$ & 3.46 & Fully Achieved & 2.73 & $\begin{array}{l}\text { Almost } \\
\text { Achieved }\end{array}$ \\
\hline
\end{tabular}


Status and proliferation of private schools in Marawi city ...

\begin{tabular}{|l|l|l|l|l|}
\hline $\begin{array}{l}\text { Cultural mission, vision, goals } \\
\text { and objectives }\end{array}$ & 3.30 & Fully Achieved & 2.94 & $\begin{array}{l}\text { Almost } \\
\text { Achieved }\end{array}$ \\
\hline $\begin{array}{l}\text { Social mission, vision, goals } \\
\text { and objectives }\end{array}$ & 3.15 & Almost Achieved & 2.70 & $\begin{array}{l}\text { Almost } \\
\text { Achieved }\end{array}$ \\
\hline $\begin{array}{l}\text { Economic mission, vision, } \\
\text { goals and objectives }\end{array}$ & 3.06 & Almost Achieved & 2.66 & $\begin{array}{l}\text { Almost } \\
\text { Achieved }\end{array}$ \\
\hline $\begin{array}{l}\text { Political mission, vision, goals } \\
\text { and objectives }\end{array}$ & 2.89 & Almost Achieved & 2.57 & $\begin{array}{l}\text { Almost } \\
\text { Achieved }\end{array}$ \\
\hline Average Weighted Mean & 3.17 & Almost Achieved & 2.72 & $\begin{array}{l}\text { Almost } \\
\text { Achieved }\end{array}$ \\
\hline
\end{tabular}

As gleaned in Table 8, both owners/administrators and teacher respondents revealed the same perceptions as to the schools; achievement of their mission, vision, goals and objectives in the religious and cultural aspects as fully achieved, while teachers in most schools rated all aspects as almost achieved in their MVGO. This indicates that these private schools are committed to a shared purpose and direction by defining clear expectations for student learning based on the realistic capability of what their schools could offer.

TABLE 9

Means Ratings of the Private Schools' Adequacy of School Facilities, Equipment and Services

\begin{tabular}{|c|c|c|c|}
\hline $\begin{array}{l}\text { School Facilities, } \\
\text { Equipment and Services }\end{array}$ & $\begin{array}{l}\text { Weighted } \\
\text { Mean }\end{array}$ & Description & Rank \\
\hline Classrooms & 3.56 & $\begin{array}{l}\text { Condition is very good and } \\
\text { functioning very well }\end{array}$ & \\
\hline Blackboards & 3.48 & $\begin{array}{l}\text { Condition is very good and } \\
\text { functioning very well }\end{array}$ & \\
\hline Chairs & 3.41 & $\begin{array}{l}\text { Condition is very good and } \\
\text { functioning very well }\end{array}$ & \\
\hline Toilet & 3.17 & $\begin{array}{l}\text { Condition is good and functioning } \\
\text { fairly well }\end{array}$ & \\
\hline Water Supply & 3.11 & $\begin{array}{l}\text { Condition is good and functioning } \\
\text { fairly well }\end{array}$ & \\
\hline Working Tables & 3.05 & $\begin{array}{l}\text { Condition is good and functioning } \\
\text { fairly well }\end{array}$ & \\
\hline Canteen & 2.94 & $\begin{array}{l}\text { Condition is good and functioning } \\
\text { fairly well }\end{array}$ & \\
\hline Library & 2.78 & $\begin{array}{l}\text { Condition is good and functioning } \\
\text { fairly well }\end{array}$ & \\
\hline Praying Room & 2.69 & $\begin{array}{l}\text { Condition is good and functioning } \\
\text { fairly well }\end{array}$ & \\
\hline Computers & 2.67 & $\begin{array}{l}\text { Condition is good and functioning } \\
\text { fairly well }\end{array}$ & \\
\hline Reading Corners & 2.47 & $\begin{array}{l}\text { Condition is limited and } \\
\text { functioning poorly }\end{array}$ & \\
\hline
\end{tabular}


Journal of Social Sciences (COES\&RJ-JSS), 7(3), pp.215-243

\begin{tabular}{|l|l|l|l|}
\hline $\begin{array}{l}\text { Clinic With Medical } \\
\text { Attendant }\end{array}$ & 2.25 & $\begin{array}{l}\text { Condition is limited and } \\
\text { functioning poorly }\end{array}$ & \\
\hline Sports Complex & 2.06 & $\begin{array}{l}\text { Condition is limited and } \\
\text { functioning poorly }\end{array}$ & \\
\hline Cooking/Baking Equipment & 1.94 & $\begin{array}{l}\text { Condition is limited and } \\
\text { functioning poorly }\end{array}$ & \\
\hline Sewing Equipment & 1.42 & Condition is missing and is needed & \\
\hline Average Weighted Mean & 2.73 & $\begin{array}{l}\text { Condition is good and functioning } \\
\text { fairly well }\end{array}$ & \\
\hline
\end{tabular}

The findings imply a condition which needs more improvement and maintenance to achieve a better equipped school and delivery of quality services. It was noticed that some of the facilities and services considered very important in a school like clinic with medical attendants and sports complex were found to be limited and functioning poorly. These could have a negative bearing on the school in terms of monitoring and securing the health of the students as well as in promoting and sports. The limited conditions of the cooking/baking equipment and the absence of sewing equipment could be an opportunity missed for the students to learn skills which could train them for future livelihood activities. This finding is might be odd.

Table 10

Mean Rating of the Private Schools' Adequacy of their Instructional Materials

\begin{tabular}{|c|c|c|c|}
\hline Instructional Materials & $\begin{array}{l}\text { Weighted } \\
\text { Mean }\end{array}$ & Description & Rank \\
\hline \multicolumn{4}{|l|}{ Print } \\
\hline Books & 2.52 & $\begin{array}{l}\text { Instructional materials are } \\
\text { available and functioning } \\
\text { fairly well }\end{array}$ & 5 \\
\hline $\begin{array}{l}\text { Magazines, Newspapers, Journals } \\
\text { and Articles }\end{array}$ & 2.44 & $\begin{array}{l}\text { Instructional materials are } \\
\text { limited and functioning } \\
\text { poorly }\end{array}$ & 7 \\
\hline Cardboards/Flashcards & 2.83 & $\begin{array}{l}\text { Instructional materials area } \\
\text { available and functioning } \\
\text { fairly well }\end{array}$ & 1 \\
\hline Materials for Project Development & 2.60 & $\begin{array}{l}\text { Instructional Materials are } \\
\text { available and functioning } \\
\text { fairly well }\end{array}$ & 2 \\
\hline $\begin{array}{l}\text { Globe, Maps, Atlas, Human } \\
\text { Anatomy Posters and other Science } \\
\text { Posters }\end{array}$ & 2.56 & $\begin{array}{l}\text { Instructional materials is } \\
\text { available and functioning } \\
\text { fairly well }\end{array}$ & 3 \\
\hline \multicolumn{4}{|l|}{ Electronics } \\
\hline $\begin{array}{ll}\text { Audio-Visual } & \text { aids } \\
\text { (TV's,DVD's/VCD's/Component) }\end{array}$ & 2.53 & $\begin{array}{l}\text { Instructional materials and } \\
\text { functioning fairly well }\end{array}$ & 4 \\
\hline Computer Assisted instruction & 2.51 & $\begin{array}{l}\text { Instructional materials are } \\
\text { limited and functioning } \\
\text { poorly }\end{array}$ & 6 \\
\hline
\end{tabular}


Status and proliferation of private schools in Marawi city ...

\begin{tabular}{|l|l|l|l|}
\hline Equipment & & & \\
\hline $\begin{array}{l}\text { Sport equipment (ball games, } \\
\text { badminton, nets, ring, etc.) }\end{array}$ & 2.35 & $\begin{array}{l}\text { Instructional materials are } \\
\text { limited and functioning } \\
\text { poorly }\end{array}$ & 8 \\
\hline $\begin{array}{l}\text { Musical Instruments (Drum Sets, } \\
\text { piano, guitar etc.) }\end{array}$ & 2.03 & $\begin{array}{l}\text { Instructional materials are } \\
\text { limited and functioning } \\
\text { poorly }\end{array}$ & 10 \\
\hline $\begin{array}{l}\text { Science Laboratory Equipment } \\
\text { (General Lab ware, Physics } \\
\text { equipment, biology Equipment, } \\
\text { Chemistry Equipment, etc.) }\end{array}$ & 2.12 & $\begin{array}{l}\text { Instructional materials are } \\
\text { limited and functioning } \\
\text { poorly }\end{array}$ & 9 \\
\hline $\begin{array}{l}\text { Average Weighted Mean } \\
\text { Standard Deviation }\end{array}$ & 2.44 & $\begin{array}{l}\text { Instructional materials are } \\
\text { limited and functioning } \\
\text { poorly }\end{array}$ & \\
\cline { 1 - 2 } & 0.38 & \multicolumn{2}{|l}{} \\
\hline
\end{tabular}

These finding suggest that school owners/administrators should give more attention to the procurement of instructional materials for use in their respective schools. Although the school facilities, equipment and service were perceived to be good and functioning fairly well, this can affect the teaching-learning effectiveness of the teachers and students. Instructional materials are educationally important and that the consequences of not having them are particularly harsh in a high-stakes.

B. Profile of the Owners/Administrators and the Teachers

Table 11

Frequency and Percentage of the Owners'/Administrators" and Teachers' Age

\begin{tabular}{|l|l|l|l|l|}
\hline \multirow{2}{*}{ Age } & \multicolumn{2}{|l|}{ Owners/Administrators } & Teachers \\
\cline { 2 - 5 } & Frequency & Percentage & Frequency & Percentage \\
\hline $\begin{array}{l}20-30 \text { years } \\
\text { old }\end{array}$ & 13 & 18.30 & 175 & 66.80 \\
\hline $\begin{array}{l}31-40 \text { years } \\
\text { old }\end{array}$ & 15 & 21.11 & 72 & 27.50 \\
\hline $\begin{array}{l}41-50 \text { years } \\
\text { old }\end{array}$ & 27 & 38.00 & 15 & 5.70 \\
\hline $\begin{array}{l}51 \text { years old } \\
\text { and above }\end{array}$ & 16 & 22.50 & & \\
\hline Total & 71 & $100 \%$ & 262 & 100 \\
\hline
\end{tabular}

The results indicate that majority of the owners/administrators were between 41 to 50 years old, considered to be the prime stage of career development where one is more committed to and stable in their jobs. For the teachers, the findings indicate that the teachers in the private schools of Marawi City are fresh graduates and young. 
Table 12

Frequency and Percentage Distribution of the Owners'/Administrators' and Teachers Civil Status

\begin{tabular}{|c|c|c|c|c|}
\hline \multirow{2}{*}{ Civil Status } & \multicolumn{2}{|c|}{ Owners/Administrators } & \multicolumn{2}{|l|}{ Teachers } \\
\hline & Frequency & Percentage & Frequency & Percentage \\
\hline Single & 9 & 12.68 & 128 & 48.90 \\
\hline Married & 58 & 81.70 & 130 & 49.60 \\
\hline Separated & 1 & 1.40 & 4 & 1.50 \\
\hline Widow & 3 & 4.22 & & \\
\hline Total & 71 & $100 \%$ & 262 & $100 \%$ \\
\hline
\end{tabular}

The civil status of the respondents indicates their level of maturity and responsibility brought about by the experiences they have gained through their status. These imply that they are experienced and responsible, fit to be administrators and teachers.

Table 13

Frequency and Percentage Distribution of the Owners'/Administrators' and Teachers' Monthly Income

\begin{tabular}{|c|c|c|c|c|}
\hline \multirow{3}{*}{ Monthly Income } & \multirow{2}{*}{\multicolumn{2}{|c|}{ Owners'/Administrators }} & & \\
\hline & & & \multicolumn{2}{|l|}{ Teachers } \\
\hline & Frequency & Percentage & Frequency & Percentage \\
\hline $\mathrm{P} 10,000$ and below & 26 & 36.00 & 254 & 96.90 \\
\hline$P 11,000-P 15,000$ & 16 & 22.50 & 8 & 3.10 \\
\hline $\mathrm{P} 16,000-\mathrm{P} 20,000$ & 7 & 9.90 & & \\
\hline P21,000 and above & 22 & 31.00 & & \\
\hline Total & 71 & $100 \%$ & 262 & $100 \%$ \\
\hline
\end{tabular}

The low salaries are take home-pay that the administrators and teachers earn are just an indication of the global economic crisis everyone is facing today. It implies that school reform are further hampered by the low salaries that the respondents receiving especially the teachers. Because of the high rate of unemployment, school teachers and administrators as well suffer from the economic recession.

Table 14

Frequency and Percentage Distribution of the Owners'/Administrators and Teachers' Highest Educational Attainment

\begin{tabular}{|c|c|c|c|c|}
\hline \multirow{2}{*}{$\begin{array}{l}\text { Highest Educational } \\
\text { Attainment }\end{array}$} & \multicolumn{2}{|c|}{ Owners/Administrators } & \multicolumn{2}{|l|}{ Teachers } \\
\hline & Frequency & Percentage & Frequency & Percentage \\
\hline College Graduate & 11 & 15.50 & 179 & 68.33 \\
\hline With Master's Unit & 23 & 32.40 & 63 & 24.04 \\
\hline Master's Degree & 22 & 31.10 & 20 & 7.63 \\
\hline Doctoral Degree & 15 & 21.1 & & \\
\hline Total & 71 & $100 \%$ & 262 & $100 \%$ \\
\hline
\end{tabular}

For the owners/administrators, the data imply that majority were equipped with sufficient academic backgrounds in taking responsibility of their positions. The teacher 
respondents likewise showed the majority were mostly fresh graduates seeking experiences though initial teaching in private schools.

Table 15

Frequency and Percentage Distribution of the Owners/Administrators and Teachers'

College/University Graduated

\begin{tabular}{|l|l|l|l|l|}
\hline \multirow{2}{*}{$\begin{array}{l}\text { College or University } \\
\text { Graduated }\end{array}$} & Owners/Administrators & Teachers & \\
\cline { 2 - 5 } & Frequency & Percentage & Frequency & Percentage \\
\hline University & 50 & 70.40 & 188 & 71.80 \\
\hline University/College & 21 & 29.60 & 74 & 28.20 \\
\hline Total & 71 & $100 \%$ & 262 & $100 \%$ \\
\hline
\end{tabular}

These results suggest that the respondents are academically-trained from the universities. Graduating from the universities may have more advantages considering that they are institutions of higher learning.

Table 16

Frequency and Percentage Distribution of the Owners'/Administrators' and Teachers' Length of Services

\begin{tabular}{|c|c|c|c|c|}
\hline \multirow[t]{2}{*}{ Length of Service } & \multicolumn{2}{|c|}{ Owners/Administrators } & \multicolumn{2}{|l|}{ Teachers } \\
\hline & Frequency & Percentage & Frequency & Percentage \\
\hline Less than 1 year & 11 & 15.50 & 109 & 41.60 \\
\hline $1-5$ years & 8 & 11.30 & 103 & 39.30 \\
\hline $6-10$ years & 26 & 36.60 & 45 & 17.20 \\
\hline $11-15$ years & 11 & 15.50 & 5 & 1.90 \\
\hline $16-20$ years & 2 & 2.80 & & \\
\hline 21 years and above & 13 & 18.30 & & \\
\hline Total & 71 & $100 \%$ & 262 & $100 \%$ \\
\hline
\end{tabular}

The length of service of the respondent is perceived to be associated with experience and commitment. The longer the length of service, the more dedication and commitment is expected in their work. This may also mean sacrifices for the sake of loyalty.

Table 17

Mean Distribution of the Teachers' Teaching Strategies Used

\begin{tabular}{|l|l|l|l|}
\hline Teaching Strategies & Weighted Mean & Description & Rank \\
\hline Cooperative Learning & 3.23 & $\begin{array}{l}\text { Teaching Strategy is } \\
\text { sometimes used }\end{array}$ & 3 \\
\hline Creative Response & 3.25 & $\begin{array}{l}\text { Teaching Strategy is } \\
\text { sometimes used }\end{array}$ & 2 \\
\hline Demonstration & 3.23 & $\begin{array}{l}\text { Teaching Strategy is } \\
\text { sometimes used }\end{array}$ & 3 \\
\hline Discovery Learning & 2.99 & $\begin{array}{l}\text { Teaching Strategy is } \\
\text { sometimes used }\end{array}$ & 6 \\
\hline Discussion/Debate & 3.11 & $\begin{array}{l}\text { Teaching Strategy is } \\
\text { sometimes used }\end{array}$ & 4 \\
\hline Experiential Learning & 2.68 & Teaching Strategy is & 8 \\
\hline
\end{tabular}


Journal of Social Sciences (COES\&RJ-JSS), 7(3), pp.215-243

\begin{tabular}{|l|l|l|l|}
\hline & & sometimes used & \\
\hline Integrated Instruction & 3.00 & $\begin{array}{l}\text { Teaching Strategy is } \\
\text { sometimes used }\end{array}$ & 5 \\
\hline Field Trip & 1.81 & $\begin{array}{l}\text { Teaching Strategy is rarely } \\
\text { used }\end{array}$ & 13 \\
\hline Hands-on & 2.56 & $\begin{array}{l}\text { Teaching Strategy is } \\
\text { sometimes used }\end{array}$ & 9 \\
\hline Inquiry & 2.70 & $\begin{array}{l}\text { Teaching Strategy is } \\
\text { sometimes used }\end{array}$ & 7 \\
\hline Laboratory & 2.07 & $\begin{array}{l}\text { Teaching Strategy is rarely } \\
\text { used }\end{array}$ & 11 \\
\hline Lecture & 3.37 & $\begin{array}{l}\text { Teaching Strategy is always } \\
\text { used }\end{array}$ & 1 \\
\hline Model \& Simulation & 1.51 & $\begin{array}{l}\text { Teaching Strategy is never } \\
\text { used }\end{array}$ & 14 \\
\hline Multimedia Instruction & 1.98 & $\begin{array}{l}\text { Teaching Strategy is rarely } \\
\text { used }\end{array}$ & 12 \\
\hline Module & 2.16 & $\begin{array}{l}\text { Teaching Strategy is rarely } \\
\text { used }\end{array}$ & 10 \\
\hline Average Weighted Mean & 2.64 & $\begin{array}{l}\text { Teaching Strategy is } \\
\text { sometimes used }\end{array}$ & \\
\hline
\end{tabular}

The finding also suggested that a positive approach of the teachers was gained to try a other teaching strategies in stimulating the interest of the learners and to motivate them to participate in the learning process.

Part II. Factors/Reasons for the Proliferation of the Private Schools.

Table 18

Religious Factors for the Proliferation of Private Schools

\begin{tabular}{|c|c|c|c|c|}
\hline \multirow[b]{2}{*}{ Religious Factors } & \multicolumn{2}{|c|}{ Owners/Administrators } & \multicolumn{2}{|l|}{ Teachers } \\
\hline & $\begin{array}{l}\text { Weighted } \\
\text { Mean }\end{array}$ & Weighted Mean & $\begin{array}{l}\text { Weighted } \\
\text { Mean }\end{array}$ & Description \\
\hline $\begin{array}{l}\text { The establishment of some integrated } \\
\text { schools provides fundamental } \\
\text { knowledge of Islam and motivates } \\
\text { students to become more responsible } \\
\text { believers in Islam. }\end{array}$ & 4.45 & $\begin{array}{l}\text { Very Strong } \\
\text { Agreement }\end{array}$ & 4.54 & $\begin{array}{l}\text { Very Strong } \\
\text { Agreement }\end{array}$ \\
\hline $\begin{array}{l}\text { To develop a well-roundedMuslim } \\
\text { personality train with skills and } \\
\text { appropriate experiences for gainful } \\
\text { living. }\end{array}$ & 4.46 & $\begin{array}{l}\text { Very Strong } \\
\text { Agreement }\end{array}$ & 4.38 & $\begin{array}{l}\text { Very Strong } \\
\text { Agreement }\end{array}$ \\
\hline $\begin{array}{l}\text { To provide quality education for the } \\
\text { youth towards building a progressive } \\
\text { Islamic society. }\end{array}$ & 4.59 & $\begin{array}{l}\text { Very Strong } \\
\text { Agreement }\end{array}$ & 4.29 & $\begin{array}{l}\text { Very Strong } \\
\text { Agreement }\end{array}$ \\
\hline $\begin{array}{l}\text { To provide authentic Islamic as an aid } \\
\text { to the traditionally passed knowledge }\end{array}$ & 4.23 & $\begin{array}{l}\text { Very Strong } \\
\text { Agreement }\end{array}$ & 4.26 & $\begin{array}{l}\text { Very Strong } \\
\text { Agreement }\end{array}$ \\
\hline
\end{tabular}


Status and proliferation of private schools in Marawi city ...

\begin{tabular}{|l|l|l|l|l|}
\hline from the past generations. & & & & \\
\hline $\begin{array}{l}\text { To promote a liberal and tolerant view } \\
\text { of religious difference in the world. }\end{array}$ & 4.03 & Fair Agreement & 4.01 & Fair Agreement \\
\hline Average Weighted Mean & 4.35 & $\begin{array}{l}\text { Very Strong } \\
\text { Agreement }\end{array}$ & 4.30 & $\begin{array}{l}\text { Very Strong } \\
\text { Agreement }\end{array}$ \\
\hline
\end{tabular}

As indicated, the owners/administrators had very strong agreement on the reasons presented such as to provide fundamental knowledge of Islam and to motivate students to become more responsible believers of Islam; to develop a well/rounded Muslim personality, trained with skills and appropriated experiences for gainful living; to provide quality education for the youth towards building a progressive Islamic society; and to provide authentic Islamic knowledge as an aid traditionally passed knowledge from past generations.

Acquisition of knowledge was a characteristic feature of the Islamic civilization. Even in the early modern times, Muslim thinkers and leaders realized the importance of education in the progress of the Muslim Community particularly, in strengthening the community against the socio-economic and cultural should be defined in relation to the spiritual reality of man and that the proper revival of the Muslims should start not just with great emphasis on education, but with greater emphasis on the right conception of knowledge starting from the college level all the way down to secondary and primary levels (Daud, 1998).

Table 19

Cultural Factors/Reasons for the proliferation of Private Schools

\begin{tabular}{|c|c|c|c|c|}
\hline \multirow[t]{2}{*}{ Cultural Factors/Reasons } & \multicolumn{2}{|c|}{$\begin{array}{ll}\text { School Owners/ } & \text { Odministrators }\end{array}$} & \multicolumn{2}{|c|}{ Teachers } \\
\hline & WM & Description & WM & Description \\
\hline $\begin{array}{l}\text { It is through various forms of } \\
\text { schooling that the next adult } \\
\text { generation can gain insights and } \\
\text { understanding of their cultural } \\
\text { traditions; values norms and } \\
\text { practices. }\end{array}$ & 3.80 & $\begin{array}{l}\text { Fair } \\
\text { Agreement }\end{array}$ & 4.14 & $\begin{array}{l}\text { Fair } \\
\text { Agreement }\end{array}$ \\
\hline $\begin{array}{l}\text { The presence of many schools } \\
\text { helps in the promotion and } \\
\text { preservation of the Meranao } \\
\text { culture by retaining students } \\
\text { especially the women within the } \\
\text { confines of Marawi City. }\end{array}$ & 3.97 & $\begin{array}{l}\text { Fair } \\
\text { Agreement }\end{array}$ & 4.01 & $\begin{array}{l}\text { Fair } \\
\text { Agreement }\end{array}$ \\
\hline $\begin{array}{l}\text { Education through formal } \\
\text { schooling guarantees the } \\
\text { continuation of culture because } \\
\text { of the curriculum that reflects } \\
\text { the norms and values which can }\end{array}$ & 3.94 & $\begin{array}{l}\text { Fair } \\
\text { Agreement }\end{array}$ & 4.11 & $\begin{array}{l}\text { Fair } \\
\text { Agreement }\end{array}$ \\
\hline
\end{tabular}




\begin{tabular}{|c|c|c|c|c|}
\hline $\begin{array}{l}\text { strengthen the cultural identity } \\
\text { of the learners. }\end{array}$ & & & & \\
\hline $\begin{array}{l}\text { Schools can facilitate or enhance } \\
\text { the sustenance and promotion of } \\
\text { cultural varieties through their } \\
\text { non-formal or extra-curricular } \\
\text { activities. }\end{array}$ & 3.90 & $\begin{array}{l}\text { Fair } \\
\text { Agreement }\end{array}$ & 4.14 & $\begin{array}{l}\text { Fair } \\
\text { Agreement }\end{array}$ \\
\hline $\begin{array}{l}\text { Schools can be effective partners } \\
\text { and agents for the actual } \\
\text { performance and observance of } \\
\text { cultural norms, values and } \\
\text { practices in the community }\end{array}$ & 4.13 & $\begin{array}{l}\text { Fair } \\
\text { Agreement }\end{array}$ & 4.20 & $\begin{array}{l}\text { Fair } \\
\text { Agreement }\end{array}$ \\
\hline Average Weighted Mean & 3.95 & $\begin{array}{l}\text { Fair } \\
\text { Agreement }\end{array}$ & 4.12 & $\begin{array}{l}\text { Fair } \\
\text { Agreement }\end{array}$ \\
\hline
\end{tabular}

Both results implied fair agreement that culture influences the proliferation of private schools.

Formal Schooling now becomes the main instrument for the transmission of culture to generations while at the same time stimulate and develop the intellect and creativity of learners.

Table 20

Social Factors/Reasons for the Proliferation of Private Schools

\begin{tabular}{|l|l|l|l|l|}
\hline Social Factors/Reasons & \multicolumn{2}{l|}{$\begin{array}{l}\text { School Owners/ } \\
\text { Administrators }\end{array}$} & Teachers \\
\cline { 2 - 5 } & $\begin{array}{l}\text { Weighted } \\
\text { Mean }\end{array}$ & Description & $\begin{array}{l}\text { Weighted } \\
\text { Mean }\end{array}$ & Description \\
\hline $\begin{array}{l}\text { Education helps improve the } \\
\text { quality of life of the Meranao } \\
\text { by promoting attitudinal } \\
\text { changes conducive to } \\
\text { development. }\end{array}$ & $\begin{array}{l}\text { Very Strong } \\
\text { Agreement }\end{array}$ & 4.29 & $\begin{array}{l}\text { Very Strong } \\
\text { Agreement }\end{array}$ & \\
\hline $\begin{array}{l}\text { The expansion of } \\
\text { opportunities provided by } \\
\text { the schools to rural and } \\
\text { urban poor such as foreign } \\
\text { languages, culturally } \\
\text { unfamiliar values and ideas } \\
\text { aside from everyday life } \\
\text { realities promotes } \\
\text { permanent literacy. }\end{array}$ & & Fair & Agreement & Agreement \\
\hline $\begin{array}{l}\text { The presence of many } \\
\text { schools can boost the living } \\
\text { condition of the people by } \\
\text { compensating home and } \\
\text { environmental disadvantages }\end{array}$ & 3.87 & Fair & & \\
\hline
\end{tabular}


Status and proliferation of private schools in Marawi city ...

\begin{tabular}{|c|c|c|c|c|}
\hline $\begin{array}{l}\text { through combination of } \\
\text { nutritional, health, } \\
\text { recreational and educational } \\
\text { activities for the youth. }\end{array}$ & & & & \\
\hline $\begin{array}{l}\text { Education helps young } \\
\text { people face the challenges in } \\
\text { search for their personal, } \\
\text { professional and social } \\
\text { identity in the society. }\end{array}$ & 4.45 & $\begin{array}{l}\text { Very Strong } \\
\text { Agreement }\end{array}$ & 4.45 & $\begin{array}{l}\text { Very Strong } \\
\text { Agreement }\end{array}$ \\
\hline $\begin{array}{l}\text { Schools can also be a key } \\
\text { factor for initiating change in } \\
\text { the promotion of a more } \\
\text { sanitary and hygienic } \\
\text { environment in the } \\
\text { community. }\end{array}$ & 4.49 & $\begin{array}{l}\text { Very Strong } \\
\text { Agreement }\end{array}$ & 4.33 & $\begin{array}{l}\text { Very Strong } \\
\text { Agreement }\end{array}$ \\
\hline Average Weighted Mean & 4.20 & $\begin{array}{l}\text { Fair } \\
\text { Agreement }\end{array}$ & 4.19 & $\begin{array}{l}\text { Fair } \\
\text { Agreement }\end{array}$ \\
\hline
\end{tabular}

These results imply very strong agreement on social factors' influence on the proliferation of private schools.

Table 21

Economic Factors/Reasons for the Proliferation of Private Schools

\begin{tabular}{|l|l|l|l|l|}
\hline \multirow{2}{*}{ Economic Factors } & \multicolumn{2}{|l|}{$\begin{array}{l}\text { Schools Owners/ } \\
\text { Administrators }\end{array}$} & \multicolumn{2}{l|}{ Teachers } \\
\cline { 2 - 5 } & WM & Description & WM & Description \\
\hline $\begin{array}{l}\text { Establishment of private schools is } \\
\text { a profitable business and can } \\
\text { increase the income of the owners } \\
\text { / stockholders. }\end{array}$ & 3.51 & $\begin{array}{l}\text { Fair } \\
\text { Agreement }\end{array}$ & 3.46 & $\begin{array}{l}\text { Fair } \\
\text { Agreement }\end{array}$ \\
\hline $\begin{array}{l}\text { Through education and in } \\
\text { producing graduates, can improve } \\
\text { the opportunity for employment } \\
\text { domestic or foreign. }\end{array}$ & 3.85 & $\begin{array}{l}\text { Fair } \\
\text { Agreement }\end{array}$ & 3.85 & Fair \\
\hline $\begin{array}{l}\text { The schools provide opportunity } \\
\text { for the students to actively } \\
\text { participate in productive economic } \\
\text { activities relevant to community } \\
\text { basic needs/ }\end{array}$ & 4.23 & $\begin{array}{l}\text { Very Strong } \\
\text { Agreement }\end{array}$ & 4.07 & Fair \\
\hline $\begin{array}{l}\text { Schools can be an instrument in } \\
\text { coping with the fast changing face } \\
\text { of technology affecting the } \\
\text { satisfaction of human needs. }\end{array}$ & 3.93 & $\begin{array}{l}\text { Fair } \\
\text { Agreement }\end{array}$ & 3.89 & $\begin{array}{l}\text { Fair } \\
\text { Agreement }\end{array}$ \\
\hline
\end{tabular}




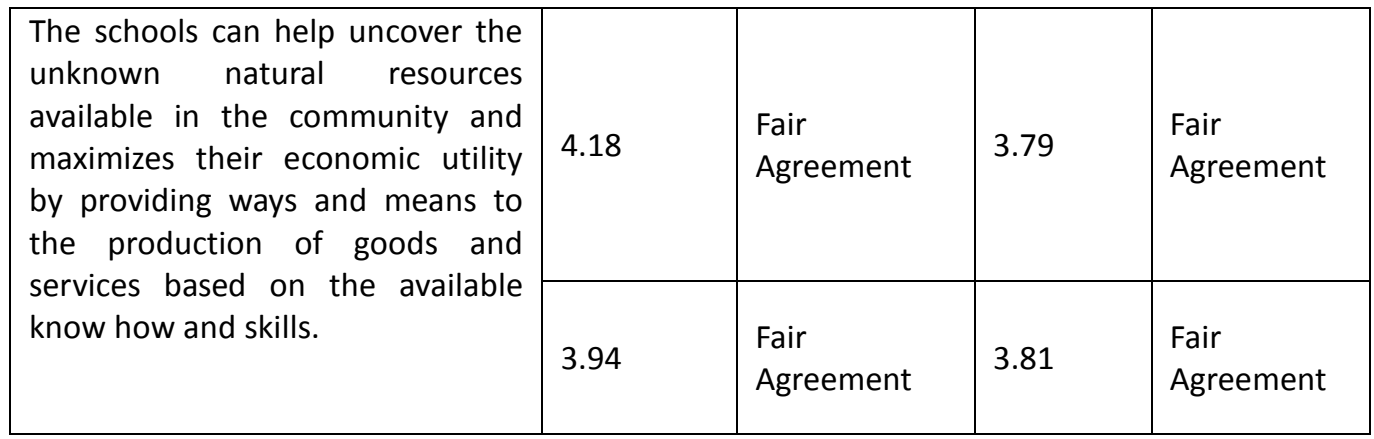

These results imply how the economy influences the establishment of schools by equipping the Meranao students with skills and knowledge that will enhance their productivity and creativity in entrepreneurship and technological advancement and participate in the global economy. This supports the study conducted in United Nations Emergency Children Fund (www.kurangayu.com/3.13.09/12:30) which revealed that economic returns from education are higher than most other kinds of investments.

Table 22

Political Factors for the Proliferation of Private Schools

\begin{tabular}{|c|c|c|c|c|}
\hline \multirow[t]{2}{*}{ Political Factors } & \multicolumn{2}{|c|}{$\begin{array}{ll}\text { School Owners/ } \\
\text { Administrators }\end{array}$} & \multicolumn{2}{|c|}{ Teachers } \\
\hline & WM & Description & WM & Description \\
\hline $\begin{array}{l}\text { The presence of many schools will } \\
\text { help in the political maturity of } \\
\text { the people in the conduct of good } \\
\text { governance and in the selection } \\
\text { of good leader through exercising } \\
\text { voting and other political rights } \\
\text { responsively. }\end{array}$ & 3.79 & Fair Agreement & 3.69 & $\begin{array}{l}\text { Fair } \\
\text { Agreement }\end{array}$ \\
\hline $\begin{array}{l}\text { It is through education that the } \\
\text { Meranao are given the } \\
\text { opportunities for their own self- } \\
\text { advancement and participate } \\
\text { actively in national affairs }\end{array}$ & 4.03 & Fair Agreement & 4.26 & $\begin{array}{l}\text { Very Strong } \\
\text { Agreement }\end{array}$ \\
\hline $\begin{array}{l}\text { The presence of many schools will } \\
\text { help provide educated citizens } \\
\text { who would be able to think and } \\
\text { consider more critically about the } \\
\text { country's political policies and } \\
\text { participate actively in political } \\
\text { development of their societies or } \\
\text { communities. }\end{array}$ & 3.90 & Fair Agreement & 3.82 & $\begin{array}{l}\text { Fair } \\
\text { Agreement }\end{array}$ \\
\hline $\begin{array}{l}\text { The school can train local } \\
\text { citizenry to develop the } \\
\text { independent decision making as a }\end{array}$ & 4.15 & Fair Agreement & 3.97 & $\begin{array}{l}\text { Fair } \\
\text { Agreement }\end{array}$ \\
\hline
\end{tabular}


Status and proliferation of private schools in Marawi city ...

\begin{tabular}{|l|l|l|l|l|}
\hline means for self-determination. & & & & \\
\hline $\begin{array}{l}\text { Through education, students are } \\
\text { introduced to a comparative } \\
\text { approach in the analysis of the } \\
\text { legal, Islamic and traditional } \\
\text { rights. }\end{array}$ & 4.24 & $\begin{array}{l}\text { Very Strong } \\
\text { Agreement }\end{array}$ & 4.06 & $\begin{array}{l}\text { Fair } \\
\text { Agreement }\end{array}$ \\
\hline Average Weighted Mean & 4.02 & Fair Agreement & 3.96 & $\begin{array}{l}\text { Fair } \\
\text { Agreement }\end{array}$ \\
\hline
\end{tabular}

The political factor for the proliferation of private schools is shown in Table 22. The table revealed fair agreement from the respondents. The Average Weighted mean for the owners/administrators was 4.02 while the teacher respondents were 3.96 .

Like the other factors, these results imply that politics has strongly influenced the proliferation of private schools with the aim of inculcating values, attitudes and skills which would help the young grow up into "mature" or effective citizens. This could also be linked with the interest of the Meranao towards politics as observed during elections and other political exercises.

Part III. Extent of School Performance

Table 23

Mean Distribution of the School by their Compliance to Government Requirements

\begin{tabular}{|l|l|l|l|l|}
\hline $\begin{array}{l}\text { Government } \\
\text { Requirements }\end{array}$ & $\begin{array}{l}\text { Owners/Administrators } \\
\text { Mean } \\
\text { Meighted }\end{array}$ & Description & $\begin{array}{l}\text { Weighte } \\
\text { d Mean }\end{array}$ & Description \\
\hline $\begin{array}{l}\text { Securing permit to } \\
\text { operate }\end{array}$ & 3.87 & Always Complied & 3.70 & Always Complied \\
\hline $\begin{array}{l}\text { Inspection and renewal } \\
\text { of permit to operate. }\end{array}$ & 3.70 & Always Complied & 3.66 & Always Complied \\
\hline $\begin{array}{l}\text { Hiring and retention of } \\
\text { teachers with } \\
\text { professional licenses. }\end{array}$ & 3.55 & Always Complied & 3.21 & $\begin{array}{l}\text { Sometimes } \\
\text { Complied }\end{array}$ \\
\hline $\begin{array}{l}\text { Hiring and retention of } \\
\text { non-license teachers }\end{array}$ & 2.89 & $\begin{array}{l}\text { Sometimes } \\
\text { Complied }\end{array}$ & 2.76 & $\begin{array}{l}\text { Sometimes } \\
\text { Complied }\end{array}$ \\
\hline $\begin{array}{l}\text { Implementation of 70- } \\
\text { 20-10 schemes of } \\
\text { revenue allocation and } \\
\text { tuition fee increase. }\end{array}$ & 2.76 & $\begin{array}{l}\text { Sometimes } \\
\text { Complied }\end{array}$ & 2.39 & Rarely Complied \\
\hline $\begin{array}{l}\text { Average Weighted } \\
\text { Mean }\end{array}$ & 3.35 & Always Complied & 3.14 & $\begin{array}{l}\text { Sometimes } \\
\text { Complied }\end{array}$ \\
\hline
\end{tabular}

As indicated by the data in Table 23, private schools in Marawi City comply with the necessary requirements to operate. These schools also recruit both licensed and nonlicensed teachers. There is a clear difference in the responses of the owners/administrators and teachers as to the implementation of the 70-20-10 scheme revenue allocation. Implementing this scheme would mean a lot to the teachers and the 
students who will be benefited by the $20 \%$ allocation intended for school improvement. On the other hand, non-compliance with these requirements would deprive students and teachers in school upgrading or accreditation

Table 24

Mean Ratings of the Schools in their Level of Passing in Standardized or Board

Examination

\begin{tabular}{|l|l|l|l|l|}
\hline \multirow{2}{*}{ Program Level } & \multicolumn{2}{|l|}{ Owners/Administrators } & Teachers & Description \\
\cline { 2 - 5 } & $\begin{array}{l}\text { Weighted } \\
\text { Mean }\end{array}$ & Description & $\begin{array}{l}\text { Weighted } \\
\text { Mean }\end{array}$ & $\begin{array}{l}\text { Very } \\
\text { Satisfactory }\end{array}$ \\
\hline Elementary level & 3.27 & Satisfactory & 2.84 & $\begin{array}{l}\text { Very } \\
\text { Satisfactory }\end{array}$ \\
\hline $\begin{array}{l}\text { Secondary or High School } \\
\text { Level }\end{array}$ & 3.25 & $\begin{array}{l}\text { Very } \\
\text { Satisfactory }\end{array}$ & 2.67 & Satisfactory \\
\hline $\begin{array}{l}\text { Vocational/Technical } \\
\text { Courses }\end{array}$ & 3.18 & $\begin{array}{l}\text { Very } \\
\text { Satisfactory }\end{array}$ & 2.47 & Satisfactory \\
\hline Tertiary Level & 2.50 & Satisfactory & 2.28 & $\begin{array}{l}\text { Very } \\
\text { Satisfactory }\end{array}$ \\
\hline Average Weighted Mean & 3.05 & $\begin{array}{l}\text { Very } \\
\text { Satisfactory }\end{array}$ & 2.56 &
\end{tabular}

The result implies that students' performance in standardized examinations such as National Achievement Test, High School Readiness Test and other Board Examinations regulated by the PRC are perceived to be very satisfactory. The selected private schools have shown very satisfactory performance compared with their counterparts in the public schools in the national examinations. Some of these schools are Ibn Sienna Integrated School, MasiricampoAbantas Memorial Science Academy, Dansalan College Foundation Inc., Senator Ninoy Aquino Foundation, JamiatuMarawi Al-Islamia, Marawi Capitol College Foundation and JamiatuMarawi Al-Islamia. For the college level, the Philippine Muslim Teachers College is one of the schools with very satisfactory performance in the Licensure Examination for Teachers, 7 out of 10 graduates who took the LET pass the examination.

However, measuring the quality of education does not lie solely on achievement tests and examinations as these have set limitations on the part of the students on what they should learn. Assessment can help everyone understand how students learn best under which conditions and with what knowledge/skills they need to learn more.

Table 25

Mean Ratings of the Respondents by their Researches and Publications

\begin{tabular}{|l|l|l|l|l|l|l|}
\hline Researches and & \multicolumn{2}{|l|}{ Owners/Administrators } & Rank & Teachers & Rank \\
\cline { 2 - 3 } \cline { 5 - 6 } Publications & $\begin{array}{l}\text { Weighted } \\
\text { Mean }\end{array}$ & Description & & $\begin{array}{l}\text { Weighted } \\
\text { Mean }\end{array}$ & Description & \\
\hline Gazette & 1.92 & Rarely & 7 & 2.03 & Rarely & 6 \\
\hline
\end{tabular}


Status and proliferation of private schools in Marawi city ...

\begin{tabular}{|l|l|l|l|l|l|l|}
\hline Socio-economic & 2.07 & Rarely & 5 & 2.33 & Rarely & 3 \\
\hline $\begin{array}{l}\text { Science } \\
\text { researches }\end{array}$ & 2.25 & Rarely & 3 & 2.40 & Rarely & 2 \\
\hline $\begin{array}{l}\text { Literary } \\
\text { publication }\end{array}$ & 2.35 & Rarely & 2 & 2.50 & Rarely & 1 \\
\hline Culture and Arts & 2.38 & Rarely & 1 & 2.01 & Rarely & 8 \\
\hline $\begin{array}{l}\text { Gender } \\
\text { Development } \\
\text { Studies }\end{array}$ & 1.96 & Rarely & 6 & 2.05 & Rarely & 7 \\
\hline $\begin{array}{l}\text { Politics and } \\
\text { Governance }\end{array}$ & 1.86 & Rarely & 8 & 2.09 & Rarely & 5 \\
\hline Local Studies & 2.13 & Rarely & 4 & 2.20 & Rarely & 4 \\
\hline $\begin{array}{l}\text { Average Weighted } \\
\text { Mean }\end{array}$ & 2.11 & $\begin{array}{l}\text { Rarely } \\
\text { Studied or } \\
\text { Published }\end{array}$ & & 2.20 & $\begin{array}{l}\text { Rarely } \\
\text { Studied or } \\
\text { Published }\end{array}$ & \\
\hline
\end{tabular}

The infrequent conduct of research studies and publications could have a negative impact on the quality of education of the private schools in terms of advancement and accreditation. In all aspects, research work is beneficial. Encouraging the teachers and students to do research studies would promote scholarly and scientific approach in learning process. The same with school publications, this promotes rapport between the administrators, teachers and students by airing issues concerning the school.

Table 26

Mean Ratings of the Schools' Extension Services and Community Outreach Programs

\begin{tabular}{|c|c|c|c|c|c|c|}
\hline \multirow{2}{*}{$\begin{array}{l}\text { Extension Services } \\
\text { and Community } \\
\text { Outreach Program }\end{array}$} & \multicolumn{2}{|c|}{ Owners/Administrators } & \multirow[t]{2}{*}{ Rank } & \multicolumn{2}{|l|}{ Teachers } & \multirow[t]{2}{*}{ Rank } \\
\hline & $\begin{array}{l}\text { Weighted } \\
\text { Mean }\end{array}$ & Description & & $\begin{array}{l}\text { Weighted } \\
\text { Mean }\end{array}$ & Description & \\
\hline $\begin{array}{ll}\text { Summer } & \text { Bridge } \\
\text { Program } & \\
\end{array}$ & 2.68 & Sometimes & 2 & 2.59 & Sometimes & 2 \\
\hline $\begin{array}{l}\text { Student Volunteer } \\
\text { Programs }\end{array}$ & 1.99 & Rarely & 11 & 2.02 & Rarely & 10 \\
\hline $\begin{array}{ll}\text { Youth } & \text { Sports } \\
\text { Programs } & \end{array}$ & 2.27 & Rarely & 6 & 2.44 & Rarely & 5 \\
\hline $\begin{array}{lr}\text { Health } & \text { Programs } \\
\text { and } & \text { Medical } \\
\text { Missions } & \\
\end{array}$ & 2.35 & Rarely & 5 & 2.10 & Rarely & 8 \\
\hline $\begin{array}{l}\text { Micro enterprising } \\
\text { and Livelihood } \\
\text { Training Programs }\end{array}$ & 2.00 & Rarely & 10 & 1.82 & Rarely & 12 \\
\hline $\begin{array}{l}\text { Environmental } \\
\text { Resource } \\
\text { Management } \\
\text { Programs }\end{array}$ & 2.13 & Rarely & 7 & 1.99 & Rarely & 11 \\
\hline $\begin{array}{ll}\text { Food } & \text { Security } \\
\text { Programs } & \end{array}$ & 2.01 & Rarely & 9 & 2.04 & Rarely & 9 \\
\hline
\end{tabular}


Journal of Social Sciences (COES\&RJ-JSS), 7(3), pp.215-243

\begin{tabular}{|l|l|l|l|l|l|l|}
\hline $\begin{array}{l}\text { Skills Development } \\
\text { Training }\end{array}$ & 2.56 & Sometimes & 3 & 2.50 & Rarely & 4 \\
\hline $\begin{array}{l}\text { Culture and Arts } \\
\text { Preservation }\end{array}$ & 2.75 & Sometimes & 1 & 2.56 & Sometimes & 3 \\
\hline $\begin{array}{l}\text { Politics and } \\
\text { Governance }\end{array}$ & 2.03 & Rarely & 8 & 2.19 & Rarely & 7 \\
\hline $\begin{array}{l}\text { Security/Peace } \\
\text { and Order }\end{array}$ & 2.68 & Sometimes & 2 & 2.63 & Sometimes & 1 \\
\hline $\begin{array}{l}\text { Planning and Rural } \\
\text { Concerns }\end{array}$ & 2.45 & Rarely & 4 & 2.28 & Rarely & 6 \\
\hline $\begin{array}{l}\text { Average Weighted } \\
\text { Mean }\end{array}$ & 2.32 & Rarely & & 2.26 & Rarely & \\
\hline
\end{tabular}

The participation of a school in extension or community outreach program is an indispensable component of a quality school. The lack of involvement would have a negative impact on the performance of the other function of the school as a social institution. This kind of community outreach program is very timely with the current demands of our society. Participating in such programs would be beneficial to the administrators, teachers and students in widening their experiences and knowledge and would help them grow professionally.

Table 27

The Relationship Between the School Profile and the Extent of Compliance with Government Requirements

\begin{tabular}{|c|c|c|c|c|}
\hline $\begin{array}{l}\text { Compliance } \\
\text { Government } \\
\text { Requirements } \\
\text { School Profile }\end{array}$ & $\mathrm{R}$ & Analysis of $r$ & $\begin{array}{l}\text { T-Test of } \\
\text { Significance }\end{array}$ & Interpretation \\
\hline Type of Operation & 0.0582 & No Correlation & 1.063854 & $\begin{array}{l}\text { Not significant } \\
\text { accept } \mathrm{Ho}^{1}\end{array}$ \\
\hline Type of Organization & 0.018 & No Correlation & 0.328522 & $\begin{array}{l}\text { Not significant } \\
\text { accept } \mathrm{Ho}^{1}\end{array}$ \\
\hline $\begin{array}{l}\text { Type of Curricula } \\
\text { Adopted }\end{array}$ & 0.0286 & No Correlation & 0.522115 & $\begin{array}{l}\text { Not significant } \\
\text { accept Ho }\end{array}$ \\
\hline Program Offerings & 0.04 & No Correlation & 0.730516 & $\begin{array}{l}\text { Not significant } \\
\text { accept Ho }\end{array}$ \\
\hline Type of building & 0.021 & No Correlation & 0.383299 & $\begin{array}{l}\text { Not significant } \\
\text { accept } \mathrm{Ho}^{1}\end{array}$ \\
\hline $\begin{array}{l}\text { Mode of Acquiring the } \\
\text { building }\end{array}$ & 0.0168 & No Correlation & 0.306615 & $\begin{array}{l}\text { Not significant, } \\
\text { accept } \mathrm{Ho}^{1}\end{array}$ \\
\hline Classroom Capacity & 0.0308 & No Correlation & 0.562314 & $\begin{array}{l}\text { Not significant, } \\
\text { accept } \mathrm{Ho}^{1}\end{array}$ \\
\hline Schools Source of Fund & 0.0576 & No Correlation & 1.052849 & $\begin{array}{l}\text { Not significant, } \\
\text { accept Ho }\end{array}$ \\
\hline
\end{tabular}

As shown, there is no relationship established between compliance with government requirements and the school profile in the terms of type of operation, type of 
organization, type of curricula adopted, program offerings, type of building, mode of acquiring the building, classroom capacity and school's source of funds.

This signifies that private schools in Marawi City, regardless of the status of its profile do comply with the requirements set by the government for them to operate. These also imply that school owners give priority to compliance with government requirements like securing the necessary permit to operate from authorized government agencies, the DepEd, CHED, and TESDA is especially important for the schools receiving fund assistance or subsidy from the government. Failure to comply with the requirements would mean delay or suspension of the financial assistance.

Table 28

The Relationship Between the Teachers' Profile and the Level of Passing in Standardized and Board Examination

\begin{tabular}{|l|l|l|l|l|}
\hline Teachers Profile & $r$ & Analysis of $r$ & $\begin{array}{l}\text { T-Test of } \\
\text { Significance }\end{array}$ & Interpretation \\
\hline Elementary & 0.078 & No Correlation & 1.209536 & $\begin{array}{l}\text { Not significant } \\
\text { accept Ho }{ }^{2}\end{array}$ \\
\hline Secondary /High School & 0.081333 & No Correlation & 1.2773 & $\begin{array}{l}\text { Not significant } \\
\text { accept Ho }{ }^{2}\end{array}$ \\
\hline Vocational & 0.077167 & No Correlation & 0.944756 & $\begin{array}{l}\text { Not significant } \\
\text { accept Ho }{ }^{2}\end{array}$ \\
\hline Tertiary/College & 0.058833 & No Correlation & 0.75933 & $\begin{array}{l}\text { Not significant } \\
\text { accept Ho }{ }^{2}\end{array}$ \\
\hline
\end{tabular}

The relationship between the teachers' profile and the level of passing in standardized and board examinations is presented in Table 28. The data revealed that there is no relationship established between the two variables in all program levels from tertiary/college down to the elementary level.

These results imply that the age, civil status, monthly income, educational attainment, school graduated and length of service of the teachers have nothing to do with the level of passing of the students from tertiary down to elementary. These suggest that the teachers' profile is not sufficient indicator to measure the academic performance of the students. Students performance is a product of socio-economic, psychological and environmental factors (www.scribd.com/doc/facotrs-affecting-studentsperformance/3.11.09/8:20)

Table 29

The Relationship Between the Owners/Administrators' Profile and their Extent of Researchers and Publications Conducted 
Journal of Social Sciences (COES\&RJ-JSS), 7(3), pp.215-243

\begin{tabular}{|c|c|c|c|c|}
\hline $\begin{array}{l}\text { Research and } \\
\text { Publication } \\
\text { Profile }\end{array}$ & $r$ & Analysis of $r$ & $\begin{array}{l}\text { T-Test of } \\
\text { Significance }\end{array}$ & Interpretation \\
\hline Age & 0.116 & $\begin{array}{lr}\text { Slight correlation, } \\
\text { almost negligible } \\
\text { relationship }\end{array}$ & 0.9841 & $\begin{array}{l}\text { Not significant } \\
\text { accept } \mathrm{Ho}^{3}\end{array}$ \\
\hline Civil Status & 0.3529 & $\begin{array}{l}\text { Slight correlation, } \\
\text { definite but small } \\
\text { relationship }\end{array}$ & 3.1781 & $\begin{array}{l}\text { Significant, } \\
\text { reject } \mathrm{Ho}^{3}\end{array}$ \\
\hline Monthly Income & $\begin{array}{l}- \\
0.0736\end{array}$ & $\begin{array}{|lr|}\text { Slight } & \text { correlation, } \\
\text { almost negligible } \\
\text { relationship }\end{array}$ & -0.6219 & $\begin{array}{l}\text { Not significant, } \\
\text { accept } \mathrm{Ho}^{3}\end{array}$ \\
\hline $\begin{array}{l}\text { Educational } \\
\text { Attainment }\end{array}$ & 0.2936 & $\begin{array}{l}\text { Slight correlation, } \\
\text { definite but small } \\
\text { relationship }\end{array}$ & 2.588 & $\begin{array}{l}\text { Significant, } \\
\text { reject } \mathrm{Ho}^{3}\end{array}$ \\
\hline $\begin{array}{l}\text { University/College } \\
\text { Graduated }\end{array}$ & 0.2866 & $\begin{array}{l}\text { Slight correlation, } \\
\text { definite but small } \\
\text { relationship }\end{array}$ & 2.5207 & $\begin{array}{l}\text { Significant, } \\
\text { reject } \mathrm{Ho}^{3}\end{array}$ \\
\hline Length of Service & 0.3171 & $\begin{array}{l}\text { Slight correlation, } \\
\text { definite but small } \\
\text { relationship }\end{array}$ & 2.8173 & $\begin{array}{l}\text { Significant, } \\
\text { reject } \mathrm{Ho}^{3}\end{array}$ \\
\hline
\end{tabular}

The relationship between the owners'/administrators' profile and the extent research and publications conduced is shown in table 29. As can be seen, the variables age and monthly income were found to have a slight correlation but negligible relationship. The ttest of significance revealed a not significant relationship, meaning age and monthly income of the owners/administrators have no relationship with their extent of research and publication conducted. The other profile variables such as civil status, educational attainment, university/college graduated and length od service were found to have a slight correlation but small relationship with their extent of research and publication conducted. The test of significance revealed that these variables have significant relationship with their extent of research and publication conducted. The hypothesis therefore is rejected.

Table 30

The Relationship Between the Owners'/Administrators' Profile and their Participation in Extension Services and Community Outreach Programs

\begin{tabular}{|c|c|c|c|c|}
\hline $\begin{array}{l}\text { Extension Services } \\
\text { and Community } \\
\text { Outreach } \\
\text { Programs } \\
\text { Owners/ } \\
\text { Administrators Profile }\end{array}$ & $r$ & Analysis of $r$ & $\begin{array}{l}\text { T-Test of } \\
\text { Significance }\end{array}$ & Interpretation \\
\hline
\end{tabular}


Status and proliferation of private schools in Marawi city ...

\begin{tabular}{|l|l|l|l|l|}
\hline Age & 0.273083 & $\begin{array}{l}\text { Slight correlation, } \\
\text { definite but small } \\
\text { relationship }\end{array}$ & $\begin{array}{l}\text { Significant, } \\
\text { reject Ho4 }\end{array}$ \\
\hline Civil Status & 0.333833 & $\begin{array}{l}\text { Slight correlation, } \\
\text { definite but small } \\
\text { relationship }\end{array}$ & $\begin{array}{l}\text { Significant, } \\
\text { reject Ho4 }\end{array}$ \\
\hline Monthly Income & 0.1305 & $\begin{array}{l}\text { Slight correlation, } \\
\text { almost negligible } \\
\text { relationship }\end{array}$ & $\begin{array}{l}\text { Not significant, } \\
\text { accept Ho4 }\end{array}$ \\
\hline $\begin{array}{l}\text { Educational } \\
\text { Attainment }\end{array}$ & 0.3765 & $\begin{array}{l}\text { Slight correlation, } \\
\text { definite but small } \\
\text { relationship }\end{array}$ & $\begin{array}{l}\text { Significant, } \\
\text { reject Ho4 }\end{array}$ \\
\hline $\begin{array}{l}\text { University/College } \\
\text { Graduated }\end{array}$ & 0.339333 & $\begin{array}{l}\text { Slight correlation, } \\
\text { definite but small } \\
\text { relationship }\end{array}$ & $\begin{array}{l}\text { Significant, } \\
\text { reject Ho4 }\end{array}$ \\
\hline Length of Service & 0.316167 & $\begin{array}{l}\text { Slight correlation, } \\
\text { definite but small } \\
\text { relationship }\end{array}$ & 2.808114 & $\begin{array}{l}\text { Significant, } \\
\text { reject Ho4 }\end{array}$ \\
\hline
\end{tabular}

The relationship between the owners'/administrators' profile and the extent of participation in extension and community outreach programs is presented in Table 30.

There was a slight correlation but small relationship with the variables age, civil status, educational attainment, university or college graduated and length of service. The assumption that there is no significant relationship between the profile of the owners/administrators and their extent of participation in extension and community outreach program is rejected. For the monthly income of the owners/administrators, it was found to have a slight correlation but negligible relationship. The computed t-test of significance indicates that there is no significant relationship between the monthly income of the owners/administrators and their extent of participation in extension and community outreach programs.

The age, civil status, educational attainment, school graduated and length of service of the owners/administrators have something to do with their interest in participating in extension and community outreach programs. Attached to the variables age, civil status and length of service are the responsibility the owners/administrators have an effect in their interest to conduct and participate in such programs. Likewise the educational attainment and school graduated from could have an influence in their interest and perceptions.

Table 31

The Difference between the Owners'/Administrators' and Teachers' Perceptions on the Factors for the Proliferation of Private Schools in Marawi City

\begin{tabular}{|l|l|l|l|}
\hline Factors & $\begin{array}{l}\text { T-Test } \\
\text { Computed } \\
\text { Value }\end{array}$ & $\begin{array}{l}\text { Critical Value } \\
\text { of T at .05 }\end{array}$ & Interpretation \\
\hline
\end{tabular}


Journal of Social Sciences (COES\&RJ-JSS), 7(3), pp.215-243

\begin{tabular}{|l|l|l|l|}
\hline Religious & 0.5403 & 1.960 & $\begin{array}{l}\text { No significant difference, } \\
\text { accept Ho5 }\end{array}$ \\
\hline Cultural & 1.5252 & 1.960 & $\begin{array}{l}\text { No significant difference, } \\
\text { accept Ho5 }\end{array}$ \\
\hline Social & 1.6008 & 1.960 & $\begin{array}{l}\text { No significant difference, } \\
\text { accept Ho5 }\end{array}$ \\
\hline Economic & 0.9847 & 1.960 & $\begin{array}{l}\text { No significant difference, } \\
\text { accept Ho5 }\end{array}$ \\
\hline Political & 0.4875 & 1.960 & $\begin{array}{l}\text { No significant difference, } \\
\text { accept Ho5 }\end{array}$ \\
\hline
\end{tabular}

This suggests that collaboration between the owners/administrators and teachers are possible towards the attainment of quality education and in the realization of the mission, vision, goals and objectives of the schools. According to Fulan (1994) as cited in www.ncrel.org/3.13.09/11:45, schools are likely to be more successful in achieving indepth learning when leaders work with the teachers and the community to build a collective educational vision that is clear, compelling, and connected to teaching and learning. This collective vision helps focus attention on what is important, motivates teachers and students, and increases the sense of shared responsibility for student learning. Schools with educational missions give educators stronger motivation and provide parents with a clearer picture of what the school values. Schools can get sidetracked toward non-productive programs, a focus on control, and uncoordinated decisions particularly when those schools serve large proportions of at-risk students. A clear vision and a common mission that identify the kind of learning to be achieved can help keep the school and the efforts of its staff and students on target.

The concerted opinion towards these factors could also mean that both owners/administrators and teachers are viewing the purpose of education in the same direction. This is also a good sign of possible teamwork for them in the improvement and success of their schools.

\section{Conclusion}

Based on the findings of the study, the following conclusions were drawn:

The private schools are operating legally, securing permit/licenses form authorized agencies and initially established as a foundation. The curricula adopted commonly have similarities. Inspired by the global trend on the Islamization of knowledge and with the success of the pioneering integrated schools in the area, newly established schools prefer the integrated curriculum in an attempt to excel in both fields of science and religion. Islam as a religion and way of life is made as an integral part of all subjects taught. Private schools in Marawi City are offering programs of study in all levels. Based on previous observations and the facts gathered in this study, even small schools offer complete programs.

The schools' type of building is influenced by the preference of the people of Marawi City to build concrete houses designed for maximum protection. The sizes of the classrooms are designed to accommodate not more than 50 students. 
School facilities, equipment and services such as classrooms, blackboards and chairs are available and functioning very well while others such as toilets, water supply, working tables, canteen, library, guidance services, computers, reading corners were also available and functioning fairly well. Clinics with medical attendant, sports complex, cooking equipment and sewing equipment were either missing and or functioning poorly.

Instructional materials such as cardboards/flashcards, materials for project development, globe, map, atlas and posters, audio visual aids and books were available and functioning fairly well. Other instructional materials like computer assisted instruction, magazines, newspapers, journal and articles, sports equipment, laboratory equipment and musical instruments were very limited and were functioning poorly.

The schools' major sources of funds are the tuition fees and subsidy from the government.

The school owners/administrator respondents of the private schools in Marawi City were 41-50 years old while the teachers were mostly 20-30. Both owners/administrators and teachers were married and receive a monthly income of P10,000 and below. The owners/administrators have master's units while the teachers were mostly college graduates and were graduates of a university. The owners/administrators had 6-10 years services while the teachers have rendered less than a year only.

Lecture is still the most commonly used teaching strategy by the teachers in the private schools.

The factors ofr the proliferation of private schools in Marawi City were based on the religious, cultural, social, economic and political as strongly agreed by the school owners and administrators as well as the teachers. It is therefore concluded that the above factors have influenced the increase in numbers of the private schools in Marawi City.

Private schools of Marawi City always comply with governments requirements particularly in securing permit/licenses to operate, inspection and renewal.

The students of private schools have a very satisfactory performance in standardized and board examination from tertiary to the elementary level.

Though rarely conducted and participated in, the private schools of Marawi City were more inclined to literary publication and science researches.

Among the many extension and community outreach programs, culture and arts preservation as well as security /peace and order programs interest the respondents more.

The profile of the private schools and their compliance with government requirements has no relationship as well as the teachers' profile and the level of passing in appropriate standardized examinations while the owners/administrators profile has a relationship with the extent of researches/publications and participation in extension or community outreach programs. 
The owners/administrators and teachers do not differ in their perceptions on the factors for the proliferation of private schools.

\section{References}

Borromeo, Roberto T. (1995) Strategies for Effective School Management.Quezon City: Phoenix Publishing house.

Calderon, Jose F. (1998) Foundations of Education.Quezon City: Rex Printing Company, INC.

Daud, Wan MohdNor Wan (1998) The Educational Philosophy and Practice of Syed Muhammad Naquib Al-Attas. Kuala Lumpur: International Institute of Islamic Thought.

Dee, Thomas S. (2004) "Are there Civic Returns to Educstion?" Journal of Public Economics

De la Croix and Doepke (2007) To segregate or Integrate Education and Politics. Paris CEPR Discussion Papers

Jimenez, Emmanuel (1992) The Relative Efficiency of Private and Public Schools in Developing Countries, World Bank POLICIY Research Bulletin Vol.3, Number 1

Jimenez, Emmanuel and Sawada Yasuyuk (2001) Public for Private: the Relationship of Between Public and Private School Enrollment in the Philippines. Economics of Education Review.

Jimenez, Emmanuel and Sawada Yasuyuk (2001) Public for Private: the Relationship of Between Public and Private School Enrollment in the Philippines. Economics of Education Review.

Lardizabal, Amparo S. (1988) Foundations of Education (Psychological, sociological and Anthropological).Manila, Philippines: Rex Book Store.

Lardizabal, Amparo S.; Bustos, Alicia S.; Bucu, Luz C, and Tangco, Maura G. (2002) Principles and Methods of Teaching.Quezon City: Phoenix Publishing House.

Mutilan, Mahid M. (2003) Leading A Ne Beginning at DepEd-ARMM. Cotabato City: Published by DepEd - ARMM

Panopio, Isabel S. , Cordero-Macdonald Felicidad V. and Reymundo, Adelisa A. (1994) SOCIOLOGY Focus on the Philippines. Quezon City: Ken Incorporated

Pangan et al, (1996) Statistics for College Students. Makati City: Grandwater Publication and Research Corporation.

Philippine Human Development Report (2002) Quality, Relevance and Access in Basic Education 
Poingan, Guimba B. (1999) Mindanao State University as an Instrument of Peace and Development in Mindanao.Unpublished Dissertation, Notre Dame University, Cotabato City

Rodriguez, Mario E. and Rodriguez, Lolita D. (2007) Thesis, Dissertation and Research Methods. Iligan City: LIMAR Publishing House.

San Mateo, Rosalinda and Tangco, Maura G. (2003) Foundation of Education II (Historical, Philosophical and Legal Foundation of Education). Quezo City: Katha Publishing Co.,INC.

Sharief, Sophia Ampuan (2007) The Status of Lanao del Sur and MarawiCittMadaris: A Baseline Study. Unpublished Dissertation, Mindanao State University, Marawi City

Tulio, Doris D. (2000) Foundations of Education Book One (Psychological, Anthropological and Sociological). Mandaluyong City: National Book Store

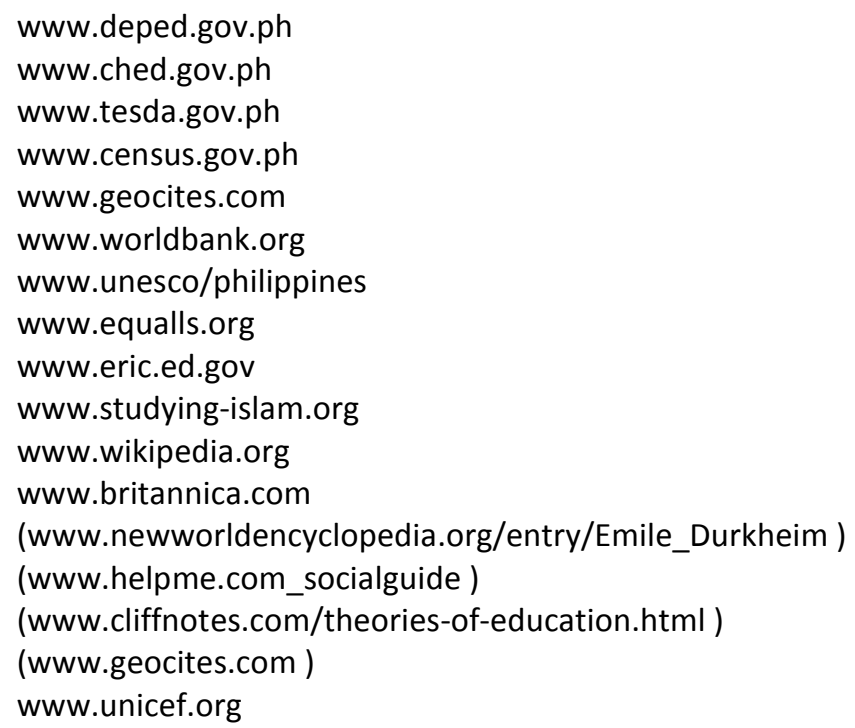

